\title{
8-(3-phenylpropyl)-1,3,7-triethylxanthine is a synthetic caffeine substitute with stronger metabolic modulator activity
}

\author{
David F. Carrageta ${ }^{\mathrm{a}, \mathrm{b}}$, Tânia R. Dias ${ }^{\mathrm{a}, \mathrm{b}}$, Ivana Jarak ${ }^{\mathrm{a}, \mathrm{b}, \mathrm{c}}$, Marco G. Alves ${ }^{\mathrm{b}}$, Pedro F. Oliveira ${ }^{\mathrm{b}, \mathrm{d}}$, \\ Mietha M. Van der Walt ${ }^{\mathrm{e}, \mathrm{f}}$, Gisella Terre'Blanche ${ }^{\mathrm{e}}$, Mariana P. Monteiro ${ }^{\mathrm{g}}$, Branca M. Silva ${ }^{\mathrm{a}, *}$ \\ ${ }^{a}$ University of Beira Interior, Rua Marquês d'Ávila e Bolama, 6201-001 Covilhã, Portugal \\ ${ }^{\mathrm{b}}$ Department of Microscopy, Laboratory of Cell Biology, Unit for Multidisciplinary Research in Biomedicine (UMIB), Institute of Biomedical Sciences Abel Salazar \\ (ICBAS), University of Porto, Rua Jorge Viterbo Ferreira, 4050-313 Porto, Portugal \\ ${ }^{\mathrm{c}}$ Department of Life Sciences, Faculty of Sciences and Technology and Centre for Functional Ecology (CFE), University of Coimbra, Coimbra, Portugal \\ d $i 3 S$ - Instituto de Investigação e Inovação em Saúde, Universidade do Porto, Rua Alfredo Allen, 4200-135 Porto, Portugal \\ e Centre of Excellence for Pharmaceutical Sciences, School of Pharmacy, North-West University, Private Bag X6001, Potchefstroom 2520, South Africa \\ ${ }^{\mathrm{f}}$ Human Metabolomics, North-West University, Private Bag X6001, Box 269, Potchefstroom 2520, South Africa \\ ${ }^{g}$ Department of Anatomy, Unit for Multidisciplinary Research in Biomedicine (UMIB), Institute of Biomedical Sciences Abel Salazar (ICBAS), University of Porto, Rua \\ Jorge Viterbo Ferreira, 4050-313 Porto, Portugal
}

\section{A R T I C L E I N F O}

\section{Keywords:}

8-(3-phenylpropyl)-1,3,7-triethylxanthine

Caffeine

Glucose metabolism

Metabolic modulator

Obesity

Xanthine

\begin{abstract}
A B S T R A C T
Caffeine is one of the most worldwide consumed methylxanthines. It is well-known for its thermogenic and cell metabolism modulating effects. Based on methylxanthines' chemical structure, 8-(3-phenylpropyl)-1,3,7-triethylxanthine (PTX) is a novel adenosine antagonist with higher receptor affinity than caffeine. Therefore, we hypothesized that PTX metabolic effects could be stronger than those of caffeine. For that purpose, murine 3T3L1 cells were cultured in the presence of increasing doses of PTX or caffeine $(0.1,1,10$ and $100 \mu \mathrm{M})$ for $24 \mathrm{~h}$. Cytotoxicity was evaluated by reduction of tetrazolium salt (MTT) and lactate dehydrogenase (LDH) release. Cell metabolites released to the culture medium were identified and quantified by proton nuclear magnetic resonance $\left({ }^{1} \mathrm{H}\right.$ NMR). Cellular oxidative profile was also evaluated. Our results showed that PTX displayed no signs of cytotoxicity at all studied concentrations. When compared with caffeine, PTX increased glucose, pyruvate, and glutamine consumption, as well as lactate, alanine, and acetate production. Additionally, PTX decreased protein oxidation, thus protecting against oxidative stress-induced damage. These results illustrate that PTX is a stronger and less cytotoxic caffeine substitute with potential applications as metabolic modulator and a good candidate for novel drug design.
\end{abstract}

\section{Introduction}

Caffeine (1,3,7-trimethylxanthine) (Fig. 1) is naturally present in common food products, globally consumed on a daily basis and the most well-characterized methylxanthine. The major sources of dietary caffeine intake are coffee (Coffea sp.) and tea (Camelia sinensis) (Frary et al. 2005). Caffeine exerts multiple physiological effects in the human body, including stimulation of the sympathetic nervous system with release of catecholamines (Acheson et al. 2004; Monteiro et al. 2018), and modulation of glucose and fatty acids metabolism (Dulloo 2011; Johansson et al. 2007), associated with increased mitochondrial activity and biogenesis (Vaughan et al. 2012). Caffeine is also known to boost physical exercise performance and endurance, being its use common among athletes (Burke 2008). Caffeine principal mechanism of action consists in the non-specific antagonism of adenosine receptors (Carrageta et al. 2018; Monteiro et al. 2016). Caffeine and adenosine have similar chemical structures, thus caffeine is able to block and inhibit the role of adenosine in cells in a competitive manner (Chen and Chern 2011; Monteiro et al. 2018), such as in the human white adipose tissue that highly expresses adenosine receptors (Vassaux et al. 1993). Caffeine is known for its thermogenic and lipolytic effects, leading to fat oxidation in adipocytes and release of fatty acids and glycerol to the bloodstream (Carrageta et al. 2018; Dulloo 2011). Moreover, caffeine consumption was reported to increase energy expenditure and promote weight loss when associated with physical exercise and calorie restriction diets (Davoodi et al. 2014; Schubert et al. 2014). Furthermore, several studies also demonstrated that caffeine in single or combined use with other drugs, such as ephedrine or albuterol, enhanced the

\footnotetext{
* Corresponding author: Faculty of Health Sciences, University of Beira Interior, Av. Infante D. Henrique, $6200-506$ Covilhã, Portugal.

E-mail address: bmcms@ubi.pt (B.M. Silva).
} 


\section{Caffeine 1,3,7-trimethylxanthine}<smiles>Cn1c(=O)c2c(ncn2C)n(C)c1=O</smiles>

\section{PTX}

\section{8-(3-phenylpropyl)-1,3,7-triethylxanthine}

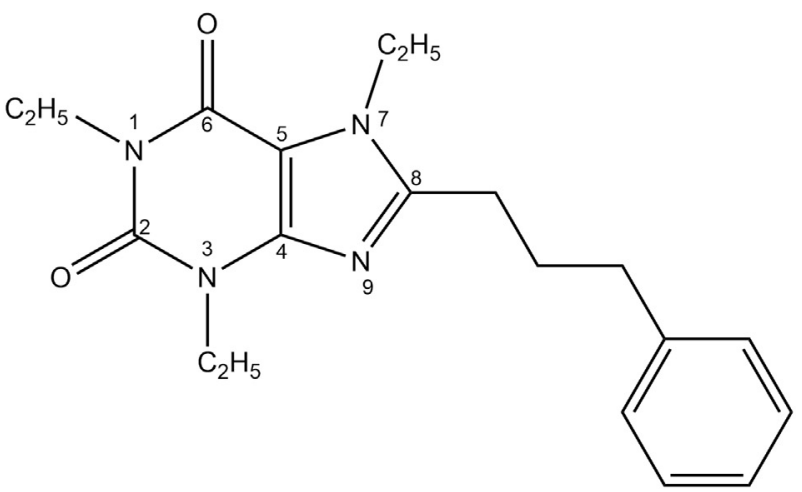

Fig. 1. - Chemical structures of caffeine and 8-(3-phenylpropyl)-1,3,7-triethylxanthine (PTX).

metabolic rate which led to weight loss (Dulloo and Miller 1986; Greenway et al. 2004; Liu et al. 2015; Liu et al. 2013). Hence, caffeine has been proposed as an adjuvant agent in obesity treatment.

Synthetic analogues of natural methylxanthines have been designed for potential pharmaceutical application as anti-obesity agents (Moro et al. 2006; Szkudelski et al. 2009). More recently, it was found that ethyl substitutions at the positions 1, 3 and 7 of the caffeine structure enhance the affinity for adenosine receptors (Van der Walt and Terre'Blanche 2015). Moreover, substitutions at position 8 with aryl or cycloalkyl groups were already reported as promising for the design of novel adenosine receptor antagonists (Baraldi et al. 2007). As a result, 8-(3-phenylpropyl)-1,3,7-triethylxanthine (PTX) (Fig. 1) was described as a novel, very potent adenosine $\mathrm{A}_{1}$ receptor antagonist obtained via structural modifications of methylxanthines structure (Van der Walt and Terre'Blanche 2015). In fact, PTX was reported to have $K_{i}$ of $0.164 \mu \mathrm{M}$, while caffeine $K_{i}$ for $A_{1} R$ is about $40-50 \mu \mathrm{M}$ (Magkos and Kavouras 2005). Herein, we hypothesize that this new analogue could have stronger effects in the metabolic modulation than caffeine. Thus, the aim of this study was to evaluate if PTX presents cytotoxic effects to 3T3-L1 cells and the potential of PTX in the modulation of cellular metabolism. Since increased metabolic activity can lead to increased oxidative stress levels (Dias et al. 2017) and this type of damage also plays an important role in pathophysiology of obesity (Marseglia et al. 2014), the effects of caffeine and PTX exposure on oxidative stress was also evaluated.

\section{Materials and methods}

\subsection{Synthesis of 8-(3-phenylpropyl)-1,3,7-triethylxanthine (PTX)}

PTX was synthesized and purified by HPLC (purity 87\%) at the School of Pharmacy, North-West University, Potchefstroom, South Africa as previously described (Van der Walt and Terre'Blanche 2015; Van der Walt et al. 2013).

\subsection{Culture of mouse preadipocyte cell line 3T3-L1}

Mouse preadipocyte cell line 3T3-L1 was purchased from a commercial supplier (Zen-Bio, Durham, NC, USA) and cultured as previously described (Moreira et al. 2015). Cells were maintained in an incubator at $37^{\circ} \mathrm{C}$ with a $5 \% \mathrm{CO}_{2}$ humidified atmosphere (Heracell 150i, Thermo Scientific, Waltham, MA, USA).

\subsection{Experimental design}

To evaluate the effects of caffeine and PTX on 3T3-L1 cells, nine experimental groups were defined: a control group without caffeine (powder, purity 99\%, C53, Sigma-Aldrich, USA) nor PTX and eight other groups with increasing doses of caffeine or PTX $(0.1,1,10$ and $100 \mu \mathrm{M})$. The stock solution of PTX was prepared in dimethyl sulfoxide (DMSO) (Labkem, Ireland) and further diluted in culture medium to obtain the intended concentrations. DMSO concentration in culture media was normalized to $0.01 \%(v / v)$. After $24 \mathrm{~h}$ treatment $(n=6$ for each condition), culture medium was collected and stored at $-80^{\circ} \mathrm{C}$ for ${ }^{1} \mathrm{H}$ NMR analysis. Cells were then detached from the culture flask using a trypsin-EDTA solution and collected for protein extraction. Total number of cells and percentage of viability was assessed by LUNA ${ }^{\mathrm{TM}}$ Automated Cell Counter (Logos Biosystems, South Korea).

\subsection{MTT viability assay}

3T3-L1 cells were seeded in 96-wells plates and cultured as described above ( $n=5$ for each condition). After $24 \mathrm{~h}$ treatment, the medium was removed and replaced with $150 \mu \mathrm{L}$ of fresh culture medium and $15 \mu \mathrm{L}$ of MTT solution ( $5 \mathrm{mg} / \mathrm{mL}$ in PBS) (Amresco, USA). Plates were then incubated in a dark environment for $3.5 \mathrm{~h}$ at $37^{\circ} \mathrm{C}$. After incubation, the culture medium was removed and $100 \mu \mathrm{L}$ DMSO were added, followed by agitation to solubilize the formazan crystals. The absorbance was measured at $570 \mathrm{~nm}$ through an Anthos $2010 \mathrm{mi}-$ croplate reader (Biochrom, Berlin, Germany). Resulting values were divided by the mean of the control group and expressed in fold variation to control group.

\subsection{Lactate dehydrogenase $(\mathrm{LDH})$ release assay}

3T3-L1 cells were seeded in 96-wells plates and cultured as described above ( $n=5$ for each condition). After $24 \mathrm{~h}$ treatment, $50 \mu \mathrm{L}$ of the culture medium was collected and transferred to a new 96-well plate. $\mathrm{LDH}$ released to the extracellular medium was quantified by the LDH Cytotoxicity Assay Kit (Thermo Scientific, Waltham, MA, USA) according to the manufacturer's instructions. Fresh culture medium was used as blank. Resulting values were divided by the mean of the control group and expressed in fold variation to control group.

\subsection{Proton nuclear magnetic resonance $\left({ }^{1} H N M R\right)$}

${ }^{1} \mathrm{H}$ NMR spectra were acquired using previously described methods (Alves et al. 2013). Cells were treated for $24 \mathrm{~h}$, as described above ( $n=6$ for each condition). A total of $180 \mu \mathrm{L}$ of culture medium of each condition was analyzed. Samples were diluted with a sodium fumarate (final concentration of $2 \mathrm{mM}$ ) and deuterated water solution (final volume of $225 \mu \mathrm{L})$, which was used as internal reference $(6.50 \mathrm{ppm})$ to 
quantify the following metabolites present in cells culture medium (multiplet, ppm): lactate (doublet, 1.33), alanine (doublet, 1.45), acetate (singlet, 1.90), pyruvate (singlet, 2.34), H1- $\alpha$-glucose (doublet, 5.22) and glutamine (multiplet, 2.45). Spectra were manually phased and baseline corrected. Chosen metabolite peaks were integrated using Amix-viewer (version 3.9.14, BrukerBiospin, Rheinstetten). Results are expressed as $\mu$ mol production or consumption per $10^{6}$ cells.

\subsection{Analysis of protein oxidation, protein nitration and lipid peroxidation}

Total protein was extracted using M-PER (Thermo Scientific, Waltham, MA, USA) according to the manufacturer's instructions. Protein samples were then quantified using a BCA Protein Assay Kit (Thermo Scientific, Waltham, MA, USA), according to the manufacturer's instructions. Protein oxidation, protein nitration and lipid peroxidation were analyzed by slot blot technique and specific antibodies, according to methods previously described (Dias et al. 2015). Briefly, for the analysis of protein oxidation the content of carbonyl groups was evaluated by derivatization of $5 \mu \mathrm{g}$ protein samples using 2,4-dinitrophenylhydrazine (DNPH) to obtain 2,4-dinitrophenyl (DNP) and followed by quantification. The slot-blot technique was performed using a Hybri-slot manifold system (Biometra, Göttingen, Germany) and the resulting PVDF membranes were incubated overnight at $4{ }^{\circ} \mathrm{C}$ with a rabbit anti-DNP (1:5000, D9656, Sigma-Aldrich, St. Louis, MO, USA). For evaluation of tyrosine residues nitration and lipid peroxidation, protein samples were diluted to a concentration of $1 \mathrm{ng} / \mu \mathrm{L}$ using PBS $1 \times$. Then, two specific antibodies, rabbit anti-nitro-tyrosine (1:5000, 9691S, Cell Signaling Technology, Netherlands) and goat anti4-hydroxynonenal (1:5000, AB5605, Merck Millipore, Temecula, USA) respectively, were used. Samples were visualized using goat anti-rabbit IgG-AP (1:5000, sc-2007, Santa Cruz Biotechnology, Heidelberg, Germany) or rabbit anti-goat IgG-AP (1:5000, A4187, Sigma-Aldrich, St. Louis, MO, USA). Membranes were then reacted with $\mathrm{ECF}^{\mathrm{TM}}$ substrate (GE Healthcare, Buckinghamshire, UK) and read using a BioRad FX-Proplus (Bio-Rad Hemel Hempstead, UK). Densities from each band were quantified using the BIO-PROFIL Bio-1D Software from Quantity One (VilberLourmat, Marne-la-Vallée, France). The density of each band was divided by the mean density of the control group and expressed in fold variation to the control group.

\subsection{Statistical analysis}

Statistical analysis was performed using the software GraphPad Prism 6 (GraphPad software, USA). The statistical significance of the groups was assessed by the student's $t$-test or by a one-way ANOVA, followed by multiple comparisons through Fisher Least Significant Difference (LSD) method. All experimental data are presented as mean \pm SEM and differences with $p<.05$ were considered significant.

\section{Results}

\subsection{PTX and caffeine cytotoxic effects in 3T3-L1 cells}

The cytotoxic profiles of PTX and caffeine to 3T3-L1 cells were assessed through two distinct in vitro assays. The MTT assay was performed to evaluate the impact of the compounds on cells' metabolic activity (Fig. 2A). Our results showed a reduction in the metabolic activity ( $0.74 \pm 0.06$-fold variation to control) by caffeine at the highest concentration $(100 \mu \mathrm{M})$, while no alterations were induced by PTX at any tested concentration.

To evaluate if the selected concentrations of caffeine or PTX could cause cellular damage and cytolysis, the LDH released to the extracellular medium was spectrophotometrically quantified (Fig. 2B). It was observed that caffeine $100 \mu \mathrm{M}$ induced a significant LDH release (2.05 \pm 0.10 -fold variation to control), while PTX did not alter LDH
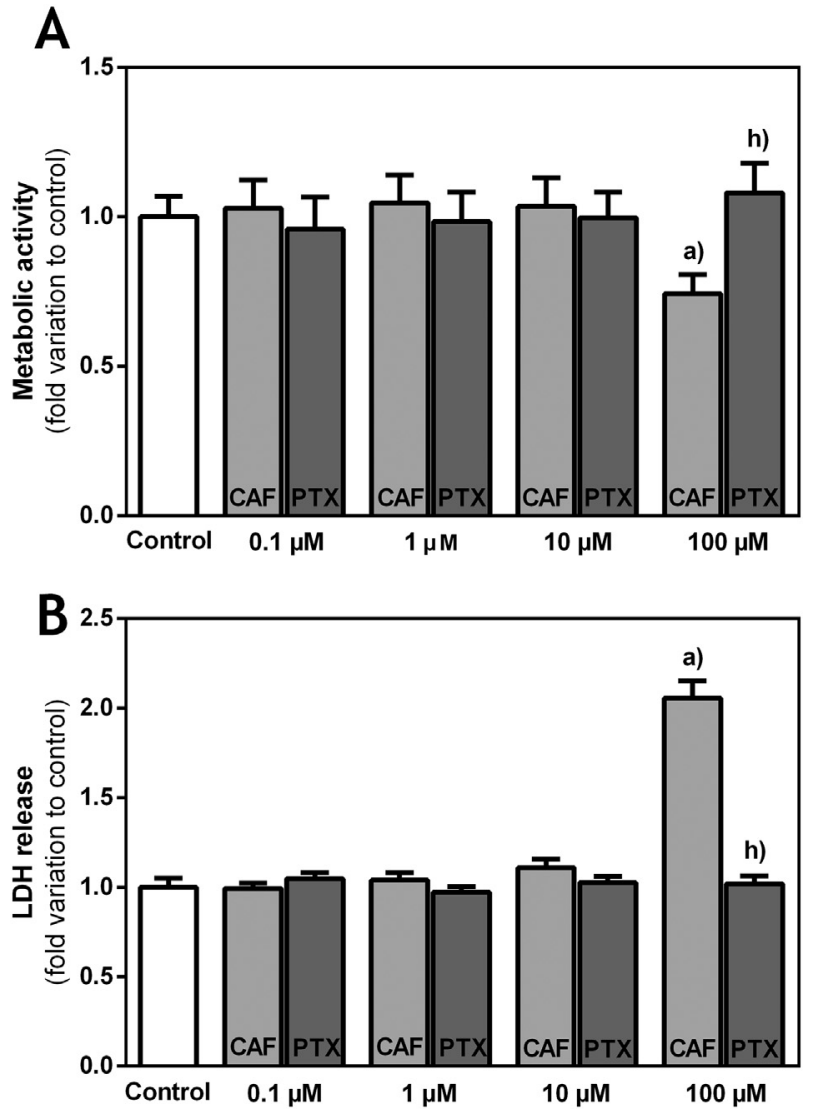

Fig. 2. - Evaluation of the metabolic activity as determined by MTT assay (A) and quantification of the released lactate dehydrogenase (LDH) (B) by 3T3-L1 cells after $24 \mathrm{~h}$ treatment with 8-(3-phenylpropyl)-1,3,7-triethylxanthine (PTX) or caffeine $(0.1,1,10$ and $100 \mu \mathrm{M})$. Results are expressed as fold variation to control and mean \pm SEM ( $n=5$ for each condition). Significantly different results $(p<.05)$ are indicated as: a) relative to control; h) relative to caffeine $100 \mu \mathrm{M}$.

release relatively to the control group. Due to cellular toxicity induced by the highest dose of caffeine $(100 \mu \mathrm{M})$, this concentration was not considered for the subsequent assays.

\subsection{PTX increases 3T3-L1 cells glycolytic activity as compared with caffeine}

Caffeine is known to modulate cellular glucose metabolism (LopesSilva et al. 2015). Hence, we evaluated the impact of the non-cytotoxic doses (up to $10 \mu \mathrm{M}$ ) of PTX and caffeine on glucose metabolism of 3T3L1 cells. Under our experimental conditions we observed that caffeine, at all the studied concentrations, did not increased glucose consumption in 3T3-L1 cells as compared with the control group (Fig. 3A). However, exposure of 3T3-L1 cells to PTX $(10 \mu \mathrm{M})$ significantly increased glucose consumption $\left(101.6 \pm 16.8 \mu \mathrm{mol} / 10^{6}\right.$ cells $)$ as compared with caffeine $\left(49.7 \pm 10.5 \mu \mathrm{mol} / 10^{6}\right.$ cells $)$, but not with control group $\left(74.8 \pm 10.7 \mu \mathrm{mol} / 10^{6}\right.$ cells). To further evaluate if the increased glucose consumption was associated with increased glycolytic activity, we quantified pyruvate (Fig. 3B) and glutamine (Fig. 3C) consumption, as well as lactate (Fig. 3D), alanine (Fig. 3E), and acetate (Fig. 3F) production. Cells exposed to PTX $10 \mu \mathrm{M}$ presented a significantly higher pyruvate and glutamine consumption $\left(12.1 \pm 3.0 \mu \mathrm{mol} / 10^{6}\right.$ cells and $28.1 \pm 4.4 \mu \mathrm{mol} / 10^{6}$ cells, respectively) when compared to caffeine $10 \mu \mathrm{M}\left(4.7 \pm 1.0 \mu \mathrm{mol} / 10^{6}\right.$ cells and $13.7 \pm 2.8 \mu \mathrm{mol} / 10^{6}$ cells, respectively), although no differences where observed when compared with the control group $(7 \pm 1 \mu \mathrm{mol} /$ $10^{6}$ cells and $20 \pm 3 \mu \mathrm{mol} / 10^{6}$ cells respectively). Moreover, PTX 
A

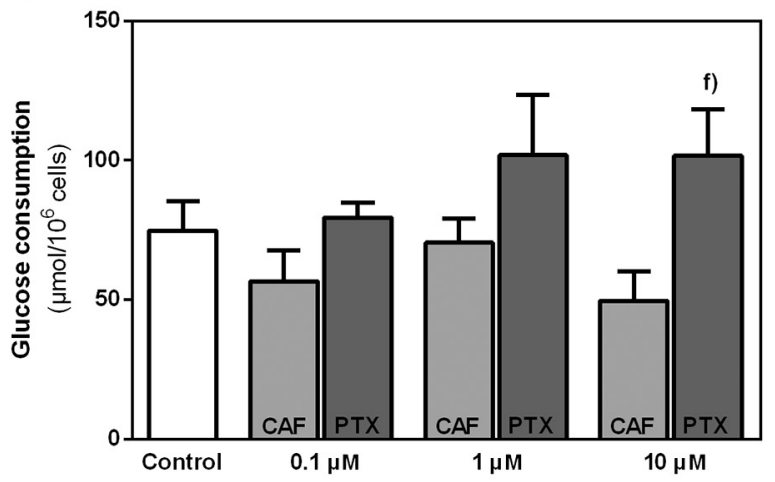

B

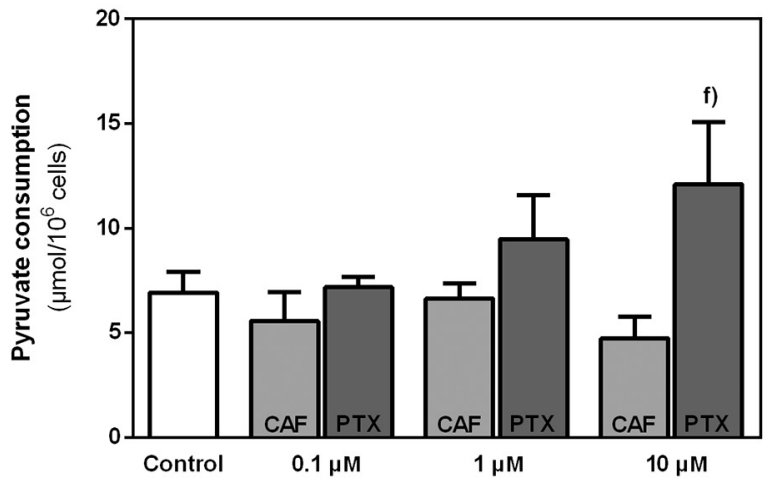

C

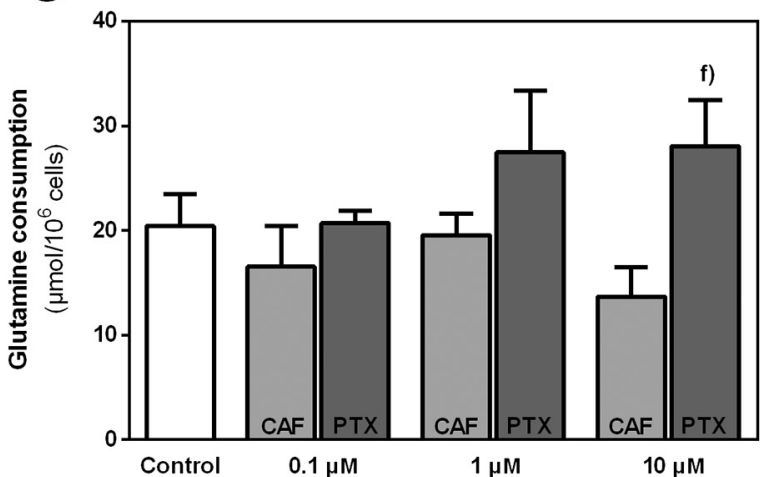

D

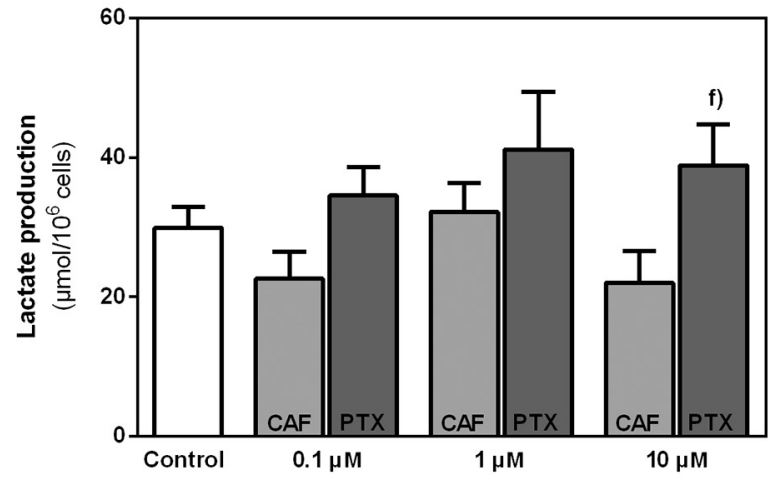

E

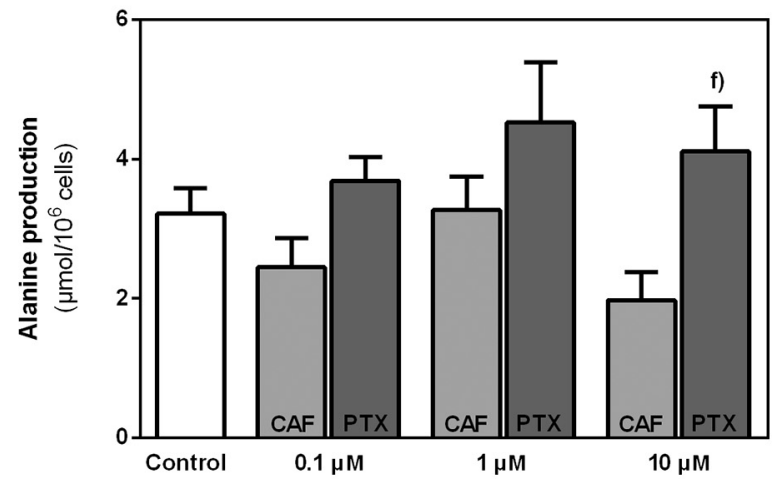

$\mathbf{F}$

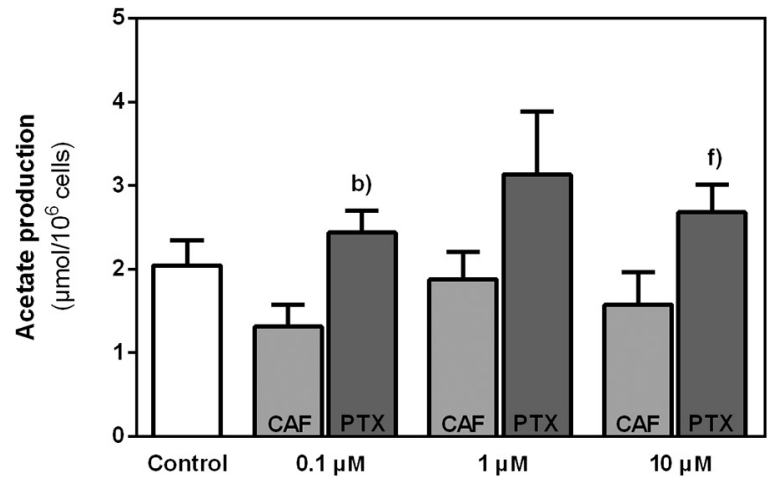

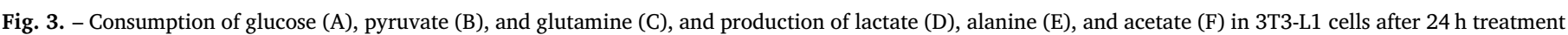

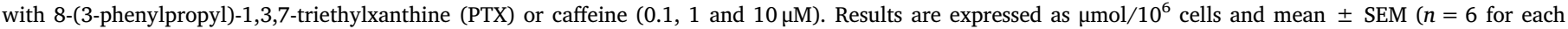
condition). Significantly different results $(\mathrm{p}<.05)$ are indicated as: b) relative caffeine $0.1 \mu \mathrm{M}$ caffeine; f) relative to caffeine $10 \mu \mathrm{M}$.

$(10 \mu \mathrm{M})$ also increased lactate and alanine production $\left(38.5 \pm 5.9 \mu \mathrm{mol} / 10^{6}\right.$ cells and $41 \pm 0.6 \mu \mathrm{mol} / 10^{6}$ cells, respectively), as compared with caffeine $\left(22 \pm 5 \mu \mathrm{mol} / 10^{6}\right.$ cells and $2.0 \pm 0.4 \mu \mathrm{mol} / 10^{6}$ cells, respectively), but not when compared with the control group $\left(29.9 \pm 2.9 \mu \mathrm{mol} / 10^{6}\right.$ cells and $3.2 \pm 0.4 \mu \mathrm{mol} / 10^{6}$ cells respectively). Our results also demonstrated an significant increase in acetate production and export from 3T3-L1 cells exposed to PTX 0.1 or $10 \mu \mathrm{M}\left(2.4 \pm 0.3 \mu \mathrm{mol} / 10^{6}\right.$ cells and $2.7 \pm 0.3 \mu \mathrm{mol} / 10^{6}$ cells, respectively) relatively to those exposed to the same concentrations of caffeine $\left(1.3 \pm 0.3 \mu \mathrm{mol} / 10^{6}\right.$ cells and $1.6 \pm 0.4 \mu \mathrm{mol} / 10^{6}$ cells, respectively), although no differences where observed when compared with the control group $\left(2.0 \pm 0.3 \mu \mathrm{mol} / 10^{6}\right.$ cells $)$.

\subsection{PTX decreases protein oxidation in 3T3-L1 cells as compared with caffeine}

Protein carbonyl groups represent an irreversible form of protein damage induced by oxidative stress. 3T3-L1 cells exposed to caffeine 1 and $10 \mu \mathrm{M}$ for $24 \mathrm{~h}$ demonstrated a significantly higher protein carbonyl content $(2.7 \pm 0.4$-fold and $2.2 \pm 0.4$-fold variation to control, respectively) relative to the control group (Fig. 4A). Contrastingly, PTX did not alter protein carbonyl content when compared to the control group. However, there was a significant decrease in protein carbonyl content of 3T3-L1 cells exposed to $1 \mu \mathrm{M}(0.41 \pm 0.06$-fold variation to control) or $10 \mu \mathrm{M}(0.49 \pm 0.08$-fold variation to control) of PTX relative to those exposed to the same concentrations of caffeine. Concerning protein nitration (Fig. 4B) and lipid peroxidation (Fig. 4C), exposure to caffeine or PTX did not alter both parameters. 

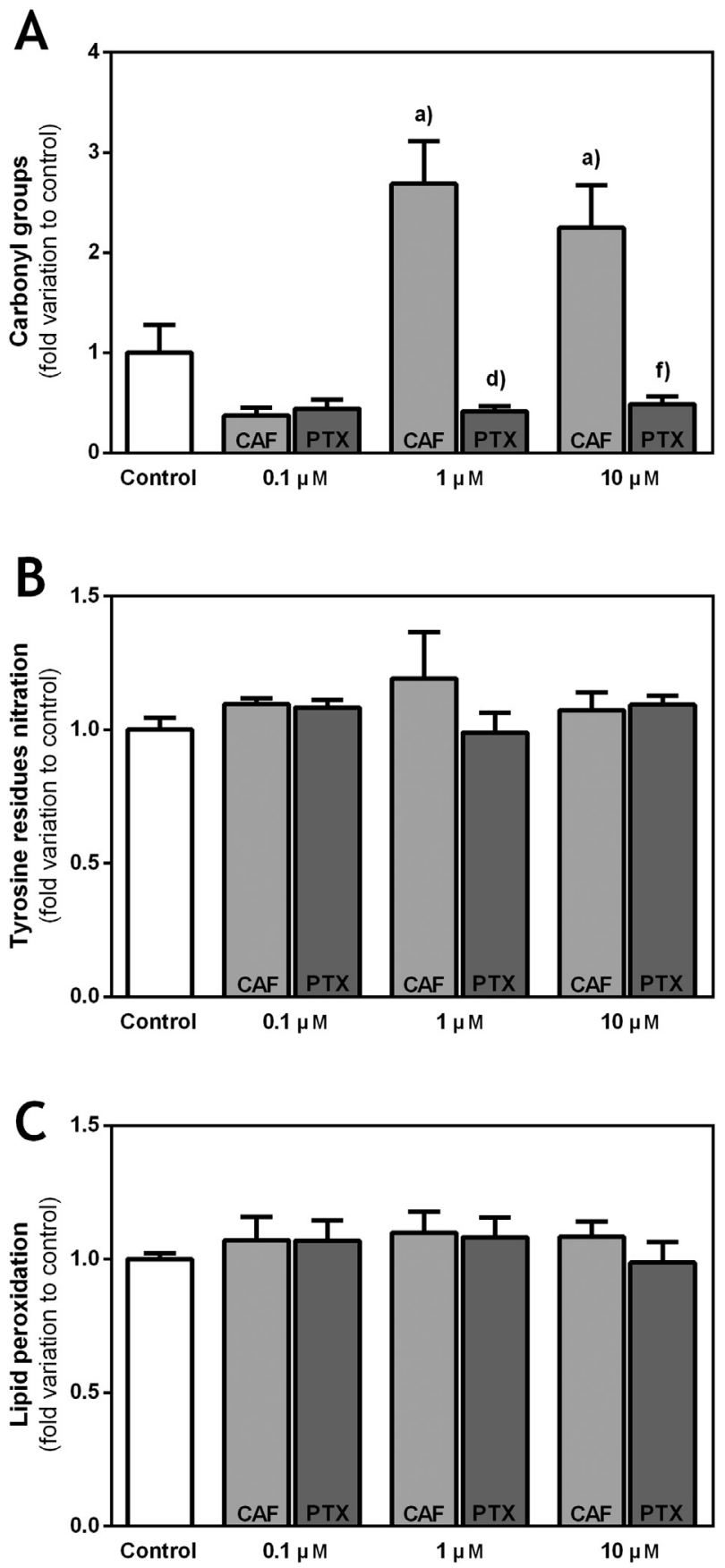

Fig. 4. - Effects of $24 \mathrm{~h}$ treatment with 8-(3-phenylpropyl)-1,3,7-triethylxanthine (PTX) or caffeine $(0.1,1$ and $10 \mu \mathrm{M})$ in carbonyl groups formation (A), tyrosine residues nitration (B) and lipid peroxidation (C) in 3T3-L1 cells. Results are expressed as fold variation to control and mean \pm SEM ( $n=6$ for each condition). Significantly different results $(\mathrm{p}<.05)$ are indicated as: a) relative to control; d) relative to caffeine $1 \mu \mathrm{M}$; f) relative to caffeine $10 \mu \mathrm{M}$.

\section{Discussion}

Caffeine is one of the most well-characterized substances worldwide. Its consumption is generally considered safe, although toxic effects to humans were reported when plasma concentrations reached $200 \mu \mathrm{M}$ (Fredholm 1985), while at $1 \mathrm{mM}$ range it is considered fatal (Anderson et al. 1999). In fact, caffeine is described to induce cellular death by apoptosis. Several mechanisms are proposed, such as apoptosis via caspase-dependent apoptosis (Kuwayama 2012), cell cycle modulation via p53 and caspases pathway (Bode and Dong 2007; He et al. 2003), or stimulation of autophagy via PI3K/Akt/mTOR pathway (Saiki et al. 2011).

The concentrations selected to be tested in this study were based on the predicted plasma concentrations achieved by regular consumption of caffeine. Caffeine content in coffee depends on the variety of beans (Coffea arabica or Coffea robusta), production, and preparation. In general, a regular cup of coffee contains 95-330 mg of caffeine $(200 \mathrm{~mL})$, instant coffee $30-70 \mathrm{mg}$ of caffeine $(200 \mathrm{~mL})$, while expresso presents high caffeine content, with $50-150 \mathrm{mg}$ of caffeine $(30 \mathrm{~mL})$ (Gonzalez de Mejia and Ramirez-Mares 2014). Caffeine is readily absorbed by the human body, with a bioavailability near to $100 \%$, reaching a plasma peak within 15-45 min when administered by oral route (Sepkowitz 2013). Moreover, an oral intake of $100 \mathrm{mg}$ of pure caffeine lead to plasma concentrations between 9 and $12 \mu \mathrm{M}$ (Teekachunhatean et al. 2013). Since PTX demonstrated higher adenosine $A_{1}$ receptor affinity than caffeine, two lower concentrations of 0.1 and $1 \mu \mathrm{M}$ and a higher concentration of $100 \mu \mathrm{M}$ were included. Our results showed that caffeine $100 \mu \mathrm{M}$ significantly impaired cellular metabolic activity and increased LDH release in the extracellular medium, suggesting 3T3-L1 cytotoxicity. In order to remove the cytotoxic variable from the subsequent assays, the higher concentration of $100 \mu \mathrm{M}$ was removed. Notably, PTX presented no cytotoxicity signs for any of the concentrations tested. These results suggest that PTX could be a safer alternative to caffeine, which is a promising feature for pharmaceutical application.

Caffeine is a known thermogenic and metabolic modulator (Dulloo 2011). It is reported to modulate glucose metabolism and increase energy expenditure (Lopes-Silva et al. 2015). Simultaneously, caffeine consumption appears to be inversely related with weight gain (Davoodi et al. 2014; Icken et al. 2015; Schubert et al. 2014). One possible explanation for these observations could be related to the effects derived from the adenosine receptors antagonism. It has been reported that adenosine receptors inhibition induces glycolysis, increasing glucose uptake and lactate production (Duarte et al. 2016; Gao et al. 1997). Simultaneously, the antagonism of adenosine $\mathrm{A}_{1}$ receptors lead to lipolysis (Szkudelski et al. 2009). Since PTX has higher affinity for $A_{1}$ receptors ( $\mathrm{K}_{\mathrm{i}}$ of $0.164 \mu \mathrm{M}$ (Van der Walt and Terre'Blanche 2015), while caffeine $K_{i}$ is about $40-50 \mu \mathrm{M}$ (Magkos and Kavouras 2005)), we hypothesized that it could have stronger metabolic effects than caffeine. In fact, when compared with caffeine, PTX $10 \mu \mathrm{M}$ significantly increased glucose, pyruvate, and glutamine consumption, and lactate and alanine production. Acetate production was significantly increased even at the lowest dose $(0.1 \mu \mathrm{M})$. Our results suggest that PTX stimulates the glycolytic pathway with a higher efficiency and at considerably lower concentrations than caffeine.

Increased metabolic activity, however, can lead to increased oxidative stress levels (Dias et al. 2017). This type of damage plays an important role in pathophysiology of several diseases, including obesity (Marseglia et al. 2014). Caffeine is usually reported as an antioxidant and associated with reduced oxidative stress biomarkers (GruckaMamczar et al. 2009; Monteiro et al. 2018). Additionally, it has been described as a protective agent against cellular damage (Ofluoglu et al. 2009) and as an efficient radical scavenger in vitro (Shi and Daly 1999). Caffeine protective effect against oxidative stress was previously associated with adenosine receptors antagonism that regulates free radicals formation (Gołembiowska and Dziubina 2012). However, some studies reported that caffeine could not protect cells against oxidative stress (Baeza et al. 2014; Inkielewicz-Stepniak and Czarnowski 2010) or may even act as prooxidant (Azam et al. 2003; Gulcin 2008). In our study, we observed that caffeine $(1$ and $10 \mu \mathrm{M})$ significantly increased protein carbonyl content, a common biomarker for protein oxidation. These results suggest that caffeine, at these conditions, acts as a prooxidant and exacerbates the protein damage caused by oxidative stress. In fact, caffeine was previously reported to induce a prooxidant environment in Sertoli cells at the same concentration range (Dias et al. 2015). Another study in U937 cells reported that a concentration of $50 \mu \mathrm{M}$ of caffeine 
also significantly increased reactive oxygen species (ROS) production (Liu and Chang 2010). Moreover, caffeine is reported to increase intracellular ROS levels in osteoblasts, causing apoptosis (Lu et al. 2008). Thus, caffeine effects may depend on the association between cell type and concentration, although the mechanisms behind antioxidant/ prooxidant activity are yet to be full elucidated. On the other hand, PTX did not alter protein oxidation as compared with the control group and decreased protein oxidation as compared with caffeine, which points out that this new compound does not comprise prooxidant effects. Additionally, PTX or caffeine did not increase lipid peroxidation or the nitration of tyrosine residues in proteins, two other common biomarkers for oxidative stress. These results additionally support the observation that PTX effectively enhances cellular metabolic activity without inducing oxidative stress.

In summary, our results highlight that PTX at the studied conditions does not induce cytotoxicity even at similar concentrations of caffeine which are toxic. Moreover, PTX is a greater modulator of cellular metabolic activity than caffeine, while reducing protein oxidation and protecting cells against oxidative stress-induced damage. These results illustrate that PTX is a synthetic substitute for caffeine with higher metabolic modulating potential and an excellent candidate for novel drug design.

\section{Conflicts of interest}

The authors declare no competing financial interest.

\section{Acknowledgements}

This work was supported by "Fundação para a Ciência e a Tecnologia" - FCT to Tânia R. Dias (SFRH/BD/109284/2015) and UMIB (PEst-OE/SAU/UI0215/2014). The work was co-funded by FEDER through the COMPETE/QREN, FSE/POPH to Marco G. Alves (PTDC/BIM-MET/4712/2014); Pedro F. Oliveira (PTDC/BBB-BQB/ 1368/2014), and POCI - COMPETE 2020 (POCI-01-0145-FEDER007491) funds.

\section{References}

Acheson, K.J., Gremaud, G., Meirim, I., Montigon, F., Krebs, Y., Fay, L.B., Gay, L.J., Schneiter, P., Schindler, C., Tappy, L., 2004. Metabolic effects of caffeine in humans: lipid oxidation or futile cycling? Am. J. Clin. Nutr. 79, 40-46.

Alves, M.G., Neuhaus-Oliveira, A., Moreira, P.I., Socorro, S., Oliveira, P.F., 2013. Exposure to 2,4-dichlorophenoxyacetic acid alters glucose metabolism in immature rat Sertoli cells. Reprod. Toxicol. 38, 81-88.

Anderson, B., Gunn, T., Holford, N., Johnson, R., 1999. Caffeine overdose in a premature infant: clinical course and pharmacokinetics. Anaesth. Intensive Care 27, 307-311.

Azam, S., Hadi, N., Khan, N.U., Hadi, S.M., 2003. Antioxidant and prooxidant properties of caffeine, theobromine and xanthine. Medical Science Monitor 9, BR325-330.

Baeza, G., Amigo-Benavent, M., Sarriá, B., Goya, L., Mateos, R., Bravo, L., 2014. Green coffee hydroxycinnamic acids but not caffeine protect human HepG2 cells against oxidative stress. Food Res. Int. 62, 1038-1046.

Baraldi, P.G., Fruttarolo, F., Tabrizi, M.A., Romagnoli, R., Preti, D., 2007. Novel 8-heterocyclyl xanthine derivatives in drug development - an update. Expert Opin. Drug Discovery 2, 1161-1183.

Bode, A.M., Dong, Z., 2007. The enigmatic effects of caffeine in cell cycle and cancer. Cancer Lett. 247, 26-39.

Burke, L.M., 2008. Caffeine and sports performance. Appl. Physiol. Nutr. Metab. 33, 1319-1334.

Carrageta, D.F., Dias, T.R., Alves, M.G., Oliveira, P.F., Monteiro, M.P., Silva, B.M., 2018. Anti-obesity potential of natural methylxanthines. J. Funct. Foods 43, 84-94.

Chen, J.F., Chern, Y., 2011. Impacts of methylxanthines and adenosine receptors on neurodegeneration: human and experimental studies. Handb. Exp. Pharmacol. 267-310.

Davoodi, S.H., Hajimiresmaiel, S.J., Ajami, M., Mohseni-Bandpei, A., Ayatollahi, S.A., Dowlatshahi, K., Javedan, G., Pazoki-Toroudi, H., 2014. Caffeine treatment prevented from weight regain after calorie shifting diet induced weight loss. Iranian Journal of Pharmaceutical Research 13, 707-718.

Dias, T.R., Alves, M.G., Bernardino, R.L., Martins, A.D., Moreira, A.C., Silva, J., Barros, A., Sousa, M., Silva, B.M., Oliveira, P.F., 2015. Dose-dependent effects of caffeine in human Sertoli cells metabolism and oxidative profile: relevance for male fertility. Toxicology 328, 12-20.

Dias, T.R., Alves, M.G., Silva, J., Barros, A., Sousa, M., Casal, S., Silva, B.M., Oliveira, P.F., 2017. Implications of epigallocatechin-3-gallate in cultured human Sertoli cells glycolytic and oxidative profile. Toxicol. in Vitro 41, 214-222.

Duarte, J.M., Cunha, R.A., Carvalho, R.A., 2016. Adenosine A(1) receptors control the metabolic recovery after hypoxia in rat hippocampal slices. J. Neurochem. 136, 947-957.

Dulloo, A.G., 2011. The search for compounds that stimulate thermogenesis in obesity management: from pharmaceuticals to functional food ingredients. Obes. Rev. 12 866-883.

Dulloo, A.G., Miller, D.S., 1986. The thermogenic properties of ephedrine/methylxanthine mixtures: human studies. Int. J. Obes. 10, 467-481.

Frary, C.D., Johnson, R.K., Wang, M.Q., 2005. Food sources and intakes of caffeine in the diets of persons in the United States. J. Am. Diet. Assoc. 105, 110-113.

Fredholm, B.B., 1985. On the mechanism of action of theophylline and caffeine. Acta Medica Scandinavica 217, 149-153.

Gao, Z.P., Downey, H.F., Sun, J., He, M.X., Mallet, R.T., 1997. Adenosine receptor blockade enhance glycolysis in hypoperfused Guinea-pig myocardium. Cardiovasc. Res. 33, 31-44.

Gołembiowska, K., Dziubina, A., 2012. The effect of adenosine A2A receptor antagonists on hydroxyl radical, dopamine, and glutamate in the striatum of rats with altered function of VMAT2. Neurotox. Res. 22, 150-157.

Gonzalez De Mejia, E., Ramirez-Mares, M.V., 2014. Impact of caffeine and coffee on our health. Trends Endocrinol. Metab. 25, 489-492.

Greenway, F.L., De Jonge, L., Blanchard, D., Frisard, M., Smith, S.R., 2004. Effect of a dietary herbal supplement containing caffeine and ephedra on weight, metabolic rate, and body composition. Obes. Res. 12, 1152-1157.

Grucka-Mamczar, E., Zalejska-Fiolka, J., Chlubek, D., Kasperczyk, S., Blaszczyk, U., Kasperczyk, A., Swietochowska, E., Birkner, E., 2009. The influence of sodium fluoride and caffeine on the activity of antioxidative enzymes and the concentration of malondialdehyde in rat liver. Fluoride 42, 105-109.

Gulcin, I., 2008. In vitro prooxidant effect of caffeine. Journal of Enzyme Inhibition and Medicinal Chemistry 23, 149-152.

He, Z., Ma, W.-Y., Hashimoto, T., Bode, A.M., Yang, C.S., Dong, Z., 2003. Induction of apoptosis by caffeine is mediated by the p53, Bax, and caspase 3 pathways. Cancer Res. 63, 4396.

Icken, D., Feller, S., Engeli, S., Mayr, A., Müller, A., Hilbert, A., de Zwaan, M., 2015. Caffeine intake is related to successful weight loss maintenance. Eur. J. Clin. Nutr. 70, 532.

Inkielewicz-Stepniak, I., Czarnowski, W., 2010. Oxidative stress parameters in rats exposed to fluoride and caffeine. Food Chem. Toxicol. 48, 1607-1611.

Johansson, S.M., Yang, J.N., Lindgren, E., Fredholm, B.B., 2007. Eliminating the antilipolytic adenosine A1 receptor does not lead to compensatory changes in the antilipolytic actions of PGE2 and nicotinic acid. Acta Physiol. 190, 87-96.

Kuwayama, H., 2012. Arachidonic acid enhances caffeine-induced cell death via caspaseindependent cell death. Sci. Rep. 2, 577.

Liu, W.H., Chang, L.S., 2010. Caffeine induces matrix metalloproteinase-2 (MMP-2) and MMP-9 down-regulation in human leukemia U937 cells via Ca2 + /ROS-mediated suppression of ERK/c-fos pathway and activation of p38 MAPK/c-Jun pathway. J. Cell. Physiol. 224, 775-785.

Liu, A.G., Smith, S.R., Fujioka, K., Greenway, F.L., 2013. The effect of leptin, caffeine ephedrine, and their combination upon visceral fat mass and weight loss. Obesity (Silver Spring) 21, 1991-1996.

Liu, A.G., Arceneaux 3rd, K.P., Chu, J.T., Jacob Jr., G., Schreiber, A.L., Tipton, R.C., Yu, Y., Johnson, W.D., Greenway, F.L., Primeaux, S.D., 2015. The effect of caffeine and albuterol on body composition and metabolic rate. Obesity (Silver Spring) 23, 1830-1835.

Lopes-Silva, J.P., Silva Santos, J.F., Branco, B.H., Abad, C.C., Oliveira, L.F., Loturco, I., Franchini, E., 2015. Caffeine ingestion increases estimated glycolytic metabolism during taekwondo combat simulation but does not improve performance or parasympathetic reactivation. PLoS One 10, e0142078.

Lu, P.Z., Lai, C.Y., Chan, W.H., 2008. Caffeine induces cell death via activation of apoptotic signal and inactivation of survival signal in human osteoblasts. Int. J. Mol. Sci. 9, 698-718.

Magkos, F., Kavouras, S.A., 2005. Caffeine use in sports, pharmacokinetics in man, and cellular mechanisms of action. Crit. Rev. Food Sci. Nutr. 45, 535-562.

Marseglia, L., Manti, S., D'Angelo, G., Nicotera, A., Parisi, E., Di Rosa, G., Gitto, E., Arrigo, T., 2014. Oxidative stress in obesity: a critical component in human diseases. Int. J. Mol. Sci. 16, 378-400.

Monteiro, J., Alves, M., Oliveira, P., Silva, B., 2016. Structure-bioactivity relationships of Methylxanthines: trying to make sense of all the promises and the drawbacks. Molecules 21, 974.

Monteiro, J., Alves, M.G., Oliveira, P.F., Silva, B.M., 2018. Pharmacological potential of Methylxanthines: retrospective analysis and future expectations. Crit. Rev. Food Sci. Nutr. 6, 1-29.

Moreira, A., Pereira, S.S., Costa, M., Morais, T., Pinto, A., Fernandes, R., Monteiro, M.P., 2015. Adipocyte secreted factors enhance aggressiveness of prostate carcinoma cells. PLoS One 10, e0123217.

Moro, S., Gao, Z.G., Jacobson, K.A., Spalluto, G., 2006. Progress in the pursuit of therapeutic adenosine receptor antagonists. Med. Res. Rev. 26, 131-159.

Ofluoglu, E., Pasaoglu, H., Pasaoglu, A., 2009. The effects of caffeine on L-arginine metabolism in the brain of rats. Neurochem. Res. 34, 395-399.

Saiki, S., Sasazawa, Y., Imamichi, Y., Kawajiri, S., Fujimaki, T., Tanida, I., Kobayashi, H., Sato, F., Sato, S., Ishikawa, K., Imoto, M., Hattori, N., 2011. Caffeine induces apoptosis by enhancement of autophagy via PI3K/Akt/mTOR/p70S6K inhibition. Autophagy 7, 176-187.

Schubert, M.M., Hall, S., Leveritt, M., Grant, G., Sabapathy, S., Desbrow, B., 2014. Caffeine consumption around an exercise bout: effects on energy expenditure, energy intake, and exercise enjoyment. J. Appl. Physiol. 117, 745-754. 
Sepkowitz, K.A., 2013. Energy drinks and caffeine-related adverse effects. JAMA 309, 243-244.

Shi, D., Daly, J.W., 1999. Chronic effects of xanthines on levels of central receptors in mice. Cell. Mol. Neurobiol. 19, 719-732.

Szkudelski, T., Szkudelska, K., Nogowski, L., 2009. Effects of adenosine A1 receptor antagonism on lipogenesis and lipolysis in isolated rat adipocytes. Physiological research 58 .

Teekachunhatean, S., Tosri, N., Rojanasthien, N., Srichairatanakool, S., Sangdee, C.,

2013. Pharmacokinetics of caffeine following a single administration of coffee Enema versus oral coffee consumption in healthy male subjects. ISRN Pharmacology 2013, 147238.

Van der Walt, M.M., Terre'Blanche, G., 2015. 1,3,7-Triethyl-substituted xanthines-possess nanomolar affinity for the adenosine A1 receptor. Bioorg. Med. Chem. 23, 6641-6649.

Van der Walt, M.M., Terre'Blanche, G., Petzer, A., Lourens, A.C., Petzer, J.P., 2013. The adenosine a(2A) antagonistic properties of selected C8-substituted xanthines. Bioorg. Chem. 49, 49-58.

Vassaux, G., Gaillard, D., Mari, B., Ailhaud, G., Negrel, R., 1993. Differential expression of adenosine $\mathrm{A} 1$ and $\mathrm{A} 2$ receptors in preadipocytes and adipocytes. Biochem. Biophys. Res. Commun. 193, 1123-1130.

Vaughan, R.A., Garcia-Smith, R., Bisoffi, M., Trujillo, K.A., Conn, C.A., 2012. Effects of caffeine on metabolism and mitochondria biogenesis in rhabdomyosarcoma cells compared with 2,4-dinitrophenol. Nutrition and Metabolic Insights 5, 59-70. 